\title{
Molecular phylogeny and shell microstructure of Fungiacava eilatensis Goreau et al. 1968, boring into mush- room corals (Scleractinia: Fungiidae), in relation to other mussels (Bivalvia: Mytilidae)
}

\author{
Masato Owada ${ }^{1,3}$, Bert W. Hoeksema ${ }^{2}$ \\ ${ }^{1}$ Department of Biological Sciences, Kanagawa University, 2946 Tsuchiya, Hiratsuka, Kanagawa, Japan \\ ${ }^{2}$ Department of Marine Zoology, Netherlands Centre for Biodiversity Naturalis, P.O. Box 9517, 2300 RA Leiden, \\ the Netherlands \\ ${ }^{3}$ E-mail:pt125365@kanagawa-u.ac.jp
}

Key words: 18s rRNA, Fungiacava, Leiosolenus, mushroom corals, rock-boring bivalves, shell microstructure

\begin{abstract}
Research on the evolution of the symbiosis between the boring mussel Fungiacava eilatensis (Bivalvia: Mytilidae) and its mushroom coral hosts (Scleractinia: Fungiidae), which requires phylogenetic reconstructions of both the Mytilidae and the Fungiidae, contributes to the understanding of the complexity of coral reef ecosystems. Previously, Fungiacava was regarded as a genus that had descended from Leiosolenus or as belonging to the subfamily Crenellinae, but no phylogenetic support has been obtained for this hypothesis. In the present study, the 18s rRNA sequences of ten mytilid species and the shell microstructures of 12 mytilids were investigated. The phylogenetic position of $F$. eilatensis is discussed in relation to its associations with its host species. The results of the molecular phylogenetic analysis indicate that $F$. eilatensis forms a sister group with Leiosolenus simplex, a livecoral-boring species within the Leiosolenus clade. Scanning electron microscope observations indicate that the shell of F. eilatensis is constructed of 3 layers: the outer shell layer with a homogeneous structure, the middle shell layer as a sheet nacreous structure, and the inner shell layer with an irregular simple prism structure. This shell microstructure of F. eilatensis is similar to that of Leiosolenus malaccanus and L. simplex. These findings show that $F$. eilatensis has descended from a coral-boring Leiosolenus species and that it would be adequate for Fungiacava to be treated as Leiosolenus. However, because of its extraordinary shell shape it has been kept as a separate genus.
\end{abstract}

\section{Contents}

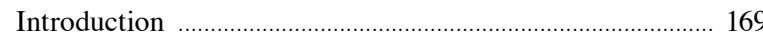

Material and methods ....................................................... 170

Analysis of molecular phylogeny ...................................... 170

Scanning electron microscope observations .................. 170

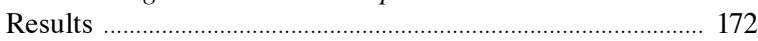

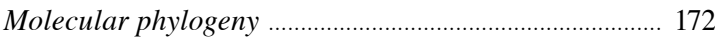

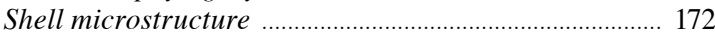

Discussion ......................................................................... 175

Phylogeny of Fungiacava and Leiosolenus ..................... 175

Taxonomical position of Fungiacava ................................ 175

Acknowledgements ................................................................. 176

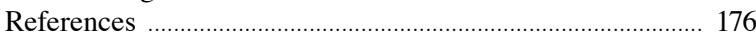

\section{Introduction}

Bivalves of the genera Fungiacava and Leiosolenus are endosymbiotic mytilids that bore into living corals (Goreau et al., 1970; Mokady et al., 1998). Shells of Fungiacava are typically flat and heart-shaped (Hoeksema and Kleemann, 2002), whereas those of Lithophaga are more or less cylindrical and torpedoshaped (Kleemann and Hoeksema, 2002). As endosymbionts they show very little intraspecific variation in shell morphology in comparison to attached species of, for instance, Mytilus (Groenenberg et al., 2011). Fungiacava eilatensis Goreau, Goreau and Neumann, 1968 , bores into 14 species of living corals that belonged to four genera and six subgenera of Fungiidae (Hoeksema and Achituv, 1993; Hoeksema and Kleemann, 2002; Hoeksema and Gittenberger, 2008), which presently are considered eight genera together (Gittenberger et al., 2011). Leiosolenus punctatus (Kleemann \& Hoeksema, 2002), exclusively recorded from Fungiidae, and Leiosolenus laevigatus (Quoy \& Gaimard, 1835), infesting many species of living corals, bore into six species of Fungiidae and nine species of five scleractinian families, respectively (Kleemann, 1980; Kleemann and Hoeksema, 2002). Consequently, among the Mytilidae, F. eilatensis has the largest number of confirmed host coral species and the largest number of hosts belonging to a single coral family, which comprises at least 50 species (listed by Gittenberger et al., 2011).

Research on the evolution of symbiosis between the monospecific genus Fungiacava and the Fungiidae is relevant to the understanding of the complexity of interspecific associations in coral reef ecosystems, for which phylogeny reconstructions of both the Mytilidae and the Fungiidae are necessary. Although phylogeny reconstructions of fungiid corals are available 
(Hoeksema, 1989, 1991a, 1993; Gittenberger et al., 2011), the phylogenetic position of F. eilatensis is not yet fully investigated. In addition, the classification of F. eilatensis is not consistent among researchers. For example, Goreau et al. (1969) described F. eilatensis as a species of the subfamily Crenellinae based on the shell form, whereas others treated Fungiacava as belonging to the subfamily Lithophaginae based on the mode of life, along with other genera of boring mussels (Morton, 1990). Therefore, the phylogenetic position of $F$. eilatensis needs to be analysed on the basis of morphological characters and DNA sequences that strongly reflect the mytilid phylogeny.

It is known that shell microstructure characters are generally consistent within each family. In the Mytilidae, however, the shell microstructure characters are relatively variable (Carter, 1990; Kobayashi, 1998, 2004; Taylor et al., 1969, 1973). This variation may support the classification of $F$. eilatensis. Furthermore, the 18s rRNA sequences of many species were investigated and deposited in the DNA Data Bank of Japan. The accumulated data are useful to reconstruct the phylogenetic position of $F$. eilatensis. In the present study, 18s rRNA sequences and the shell microstructures of ten and 12 mytilid species, respectively, were investigated in order to reconstruct the phylogenetic position of $F$. eilatensis and to classify the genus Fungiacava in relation to other mytilids.

\section{Material and methods}

\section{Analysis of molecular phylogeny}

Specimens of $F$. eilatensis were obtained from two specimens of the mushroom coral Sandalolitha ro-

Table 1. Amplification and sequencing primers for 18s rRNA sequence. $22 \mathrm{~F}$ and $1789 \mathrm{R}$ were used to amplify in the PCR.

\begin{tabular}{ll}
\hline Primer & 5'-3' sequence \\
\hline $22 \mathrm{~F}$ & WAYCTGGTTGATCCTGCCAGT \\
$393 \mathrm{~F}$ & AGGGTTYGRYTCCGGAGA \\
$393 \mathrm{R}$ & TCTCCGGAATCGAACCCT \\
$762 \mathrm{~F}$ & AGTGTCCTGGGTGGCCRGAAMGTTTA \\
$762 \mathrm{R}$ & TAAACKTTCYGGCCACCCGAGACACT \\
$1000 \mathrm{~F}$ & CTGACCATAAACGATGCC \\
$1100 \mathrm{R}$ & GCTATKGRARYAACKCCGSC \\
$1418 \mathrm{~F}$ & KTTYAGCCACACGAGATYGAGC \\
$1418 \mathrm{R}$ & GCTCRATCTCGTGTGGCTRAAM \\
$1789 \mathrm{R}$ & GATCCTTCYGCAGGTTCACCTAC \\
\hline
\end{tabular}

busta (Quelch, 1886) collected at Ternate, northern Molluccas, Indonesia (October 2009). After sampling, the specimens were directly fixed in $95 \%$ ethanol. Total DNA was extracted from the fixed soft tissue by using DNeasy Blood \& Tissue Kit (QIAGEN). The sequence encoding the 18s rRNA was amplified using Premix Ex Taq and the polymerase chain reaction (PCR) thermal cycler PERSONAL (TaKaRa). The PCR amplification conditions consisted of denaturation $\left(94^{\circ} \mathrm{C}\right.$ and $\left.30 \mathrm{~s}\right)$, annealing $\left(58^{\circ} \mathrm{C}\right.$ and $\left.30 \mathrm{~s}\right)$, extension $\left(72^{\circ} \mathrm{C}\right.$ and $\left.1 \mathrm{~min}\right)$ and 30 cycles. Used primers are given in Table 1. The PCR products were purified using ExoSAP-IT (USB Corporation), and the sequencing reaction was performed using BigDye Terminator v3.1 Cycle Sequencing Kit (ABI PRISM). The determination of DNA sequence was carried out using 3130 Genetic Analyzer (ABI PRISM).

The sequence data were aligned using ClustalW version 1.8 (Thompson et al., 1997); gaps and sites without confirmed homology were excluded from the analyses. Thirteen species belonging to nine families that are related to Mytilidae were used as outgroups. A molecular phylogenetic tree was constructed using both the maximum likelihood and Bayesian methods, and a strict consensus tree was computed from the two trees. The model for maximum likelihood analysis was determined using Modeltest version 3.7 (Posada and Crandall, 1998), and the tree was constructed using the likelihood ratchet algorithm (Vos, 2003), which was run 2000 times by using PAUP* version 4.0b10 (Swofford, 1997); the bootstrap replication number was 1000 times. The model for Bayesian analysis was determined using Mrmodeltest version 2.3 (Posada and Buckley, 2004), and the tree was constructed using MrBayes version 3.1.2 (Ronquist and Huelsenbeck, 2003). This program was run for $5,000,000$ generations, with sampling every 1000th generation. The $18 \mathrm{~s}$ rRNA-encoding sequences of 10 species that were determined in this study were registered in the DNA Data Bank of Japan. Species names and accession numbers of the analysed samples are given in Table 2 .

\section{Scanning electron microscope observations}

After removal of soft tissues, the shells were cleaned and desiccated, and mechanically fragmented with a hammer. The fracture surfaces were coated with platinum by using ion coater JFC-1600 (JEOL) and observed under a scanning electron microscope (SEM) JSM-T20 (JEOL). The shell microstructure was identified on the 
Table 2. Species of bivalves used for molecular phylogenetic analysis.

\begin{tabular}{|c|c|c|c|}
\hline Family & Species & $\begin{array}{l}\text { "DDBJ/EMBI/GenBank } \\
\text { accession number" }\end{array}$ & Reference \\
\hline \multirow[t]{38}{*}{ Mytilidae } & Adipicola arcuatilis Dell, 1995 & AF221644 & Distel et al. (2000) \\
\hline & Adula aff. californiensis (Philippi, 1847) & AB569155 & this study \\
\hline & Adula falcatoides Habe, 1955 & AB569156 & this study \\
\hline & Bathymodiolus childressi Gustafson et al., 1998 & AF221641 & Distel et al. (2000) \\
\hline & Benthomodiolus lignocola Dell, 1987 & AF221648 & Distel et al. (2000) \\
\hline & Botula fusca (Gmelin, 1791) & AB569157 & this study \\
\hline & Brachidontes exustus (Linnaeus, 1758) & AF229623 & Campbell (2000) \\
\hline & Fungiacava eilatensis Goreau et al., 1968 & AB569158 & this study \\
\hline & Geukensia demissa (Dillwyn, 1817) & L33450 & Kenchington et al. (1995) \\
\hline & Gigantidas gladius Cosel \& Marshall, 2003 & AY649821 & Jones et al. (2006) \\
\hline & Hormomya domingensis (Lamarck, 1819) & AF117736 & Distel (2000) \\
\hline & Hormomya mutabilis (Gould, 1861) & AB201233 & Owada (2007) \\
\hline & Idas arcuatilis (Dell, 1995) & AF221643 & Distel et al. (2000) \\
\hline & Idas macdonaldi Gustafson et al., 1998 & AF221647 & Distel et al. (2000) \\
\hline & Idas washingtonia (Bernard, 1978) & AF221645 & Distel et al. (2000) \\
\hline & Leiosolenus curtus (Liscke, 1874) & AB201235 & Owada (2007) \\
\hline & Leiosolenus hanleyanus (Reeve, 1857) & AB569159 & this study \\
\hline & Leiosolenus lithura (Pilsbry, 1905) & AB201236 & Owada (2007) \\
\hline & Leiosolenus malaccanus (Reeve, 1857) & AB569160 & this study \\
\hline & Leiosolenus nasutus (Philippi, 1846) & AB569161 & this study \\
\hline & Leiosolenus obesus (Philippi, 1847) & AB201237 & Owada (2007) \\
\hline & Leiosolenus plumula (Hanley, 1843) & AB569162 & this study \\
\hline & Leiosolenus simplex (Iredale, 1939) & AB569163 & this study \\
\hline & Lithophaga antillarum (d'Orbigny, 1853) & AB201234 & Owada (2007) \\
\hline & Lithophaga lithophaga (Linnaeus, 1758) & AF124208 & Distel (2000) \\
\hline & Lithophaga nigra (d’Orbigny, 1853) & AF124209 & Distel (2000) \\
\hline & Modiolus modiolus (Linnaeus, 1758) & AF124210 & Distel (2000) \\
\hline & Modiolus auriculatus (Krauss, 1848) & AF117735 & Distel (2000) \\
\hline & Modiolus philippinarum (Hanley, 1843) & AB201232 & Owada (2007) \\
\hline & Musculus cupreus (Gould, 1861) & AB569164 & this study \\
\hline & Musculus discors (Linnaeus, 1767) & AF124206 & Distel (2000) \\
\hline & Musculista senhousia (Benson, 1842) & AF124207 & Distel (2000) \\
\hline & Myrina pacifica Dall et al., 1938 & AF221646 & Distel et al. (2000) \\
\hline & Mytilus edulis Linnaeus, 1758 & L33448 & Kenchington et al. (1995) \\
\hline & Mytilus galloprovincialis Lamarck, 1819 & L33452 & Kenchington et al. (1995) \\
\hline & Mytilus trossulus Gould, 1850 & L33453 & Kenchington et al. (1995) \\
\hline & Septifer bilocularis (Linnaeus, 1758) & AF229622 & Campbell (2000) \\
\hline & Tamu fisheri Gustafson et al., 1998 & AF221642 & Distel et al. (2000) \\
\hline \multirow[t]{2}{*}{ Arcidae } & Arca noae Linnaeus, 1758 & X90960 & unpublidhed data \\
\hline & Barbatia barbata (Linnaeus, 1758) & AF207646 & unpublished data \\
\hline Noetiidae & Striarca lactea (Linnaeus, 1758) & AF120531 & Giribet and Wheeler (2002) \\
\hline Glycymerididae & Glycymeris insubrica (Brocchi, 1814) & AF207647 & unpublished data \\
\hline \multirow[t]{2}{*}{ Pteriidae } & Pinctada fucata (Gould, 1850) & AY028625 & unpublished data \\
\hline & Pteria hirundo (Linnaeus, 1758) & AF120532 & Giribet and Wheeler (2002) \\
\hline Isognomonidae & Isognomon isognomum (Linnaeus, 1758) & AF229621 & Campbell (2000) \\
\hline Pinnidae & Atrina pectinata (Linnaeus, 1767) & X90961 & unpublished data \\
\hline Limidae & Lima lima (Linnaeus, 1758) & AF120533 & Giribet and Wheeler (2002) \\
\hline \multirow[t]{2}{*}{ Ostreidae } & Crassostrea gigas (Thunberg, 1793) & AB064942 & unpublished data \\
\hline & Ostrea edulis Linnaeus, 1758 & L49052 & Frischer et al. (1998) \\
\hline \multirow[t]{2}{*}{ Pectinidae } & Chlamys islandica (Müller, 1776) & L11232 & Kenchington et al. (1993) \\
\hline & Pecten maximus (Linnaeus, 1758) & L49053 & Frischer et al. (1998) \\
\hline
\end{tabular}


Table 3. Sampling localities and patterns of shell microstructures. The symbol ${ }^{\dagger}$ indicates species described by Owada (2009). FP: fibrous prism structure, Ho: homogeneous structure, ISP: irregular simple prism structure, ISpP: irregular spherulitic prism structure, SN: sheet nacreous structure.

\begin{tabular}{|c|c|c|c|c|}
\hline Species & Locality & Outer shell layer & Middle shell layer & Inner shell layer \\
\hline Adula aff. californiensis & Waiheke island, New Zealand & ISP & SN & ISP \\
\hline Adula falcatoides ${ }^{\dagger}$ & Wakkanai, Hokkaido, Japan & ISP+Ho & SN & ISP \\
\hline Botula fusca ${ }^{\dagger}$ & Haneji inland sea, Okinawa, Japan & Ho & SN & ISP \\
\hline Brachidontes setigera & Haneji inland sea, Okinawa, Japan & ISP & SN & ISP \\
\hline Fungiacava eilatensis & Ternate, northern Moluccas, Indonesia & Ho & SN & ISP \\
\hline Hormomya mutabilis & Miyako island, Okinawa, Japan & Ho+ISP & SN & ISP+SN \\
\hline Leiosolenus curtus ${ }^{\dagger}$ & Oiso, Kanagawa, Japan & ISP+Ho & SN & ISP \\
\hline Leiosolenus hanleyanus ${ }^{\dagger}$ & Malakal islet, Palau islands & Ho & SN & ISP \\
\hline Leiosolenus lithura & Kita-Nashiro, Okinawa, Japan & Ho & SN & ISP \\
\hline Leiosolenus malaccanus ${ }^{\dagger}$ & Kita-Nashiro, Okinawa, Japan & Ho & SN & ISP \\
\hline Leiosolenus nasutus ${ }^{\dagger}$ & Malakal islet, Palau islands & ISP+Ho & SN & ISP \\
\hline Leiosolenus obesus ${ }^{\dagger}$ & Kita-Nashiro, Okinawa, Japan & ISP+Ho & SN & ISP \\
\hline Leiosolenus plumula & Kita-Nashiro, Okinawa, Japan & Ho & SN & ISP \\
\hline Leiosolenus simplex & Minamata, Kumamoto, Japan & Ho & SN & ISP \\
\hline Lithophaga antillarum ${ }^{\dagger}$ & Kyota, Okinawa, Japan & ISP+ISpP & SN & ISP \\
\hline Lithophaga nigra & Kita-Nashiro, Okinawa, Japan & ISP+ISpP & SN & ISP \\
\hline Modiolus auriculatus & Nashiro, Okinawa, Japan & Ho+ISP & SN & ISP \\
\hline Modiolus flavidus & Haneji inland sea, Okinawa, Japan & Ho & SN & ISP \\
\hline Modiolus philippinarum & Awase tideland, Okinawa, Japan & Ho+ISP & SN & ISP \\
\hline Musculus cupreus & Miura, Kanagawa, Japan & Ho & SN & ISP \\
\hline Musculista senhousia & Kanazawa-Hakkei, Kanagawa, Japan & Ho & SN & ISP \\
\hline Mytilus galloprovincialis & Kanazawa-Hakkei, Kanagawa, Japan & FP & SN & $\mathrm{SN}$ \\
\hline Septifer bilocularis & Untenbaru, Okinawa, Japan & ISP & SN & $\mathrm{ISP}+\mathrm{SN}$ \\
\hline
\end{tabular}

basis of the features described by Taylor et al. (1969, 1973) and Carter (1990). Species names and sampling localities of the observed samples are given in Table 3.

\section{Results}

\section{Molecular phylogeny}

The 18s rRNA-encoding sequences consisted of 17211742 bp long. After alignment, the analysed sequences were 1681 bp long, with 361 variable sites. In the maximum likelihood analysis, the $\operatorname{TrNef}+\mathrm{I}+\mathrm{G}$ model was selected by Modeltest, and the likelihood index $(-\ln L)$ of the constructed tree was 6968.1327. In the Bayesian method, the SYM + I + G model was selected by Mrmodeltest. A strict consensus tree was computed from these 2 trees (Fig. 1).

The strict consensus tree topology indicates that the phylogenetic relationships between subfamilies are not clear although the Mytilidae appears to be monophyletic (bootstrap value $>50 \%$ and Bayesian posterior probability > 0.90). Lithophaga, Modiolus, and Mytilus are monophyletic, but Idas, Leiosolenus, and Musculus not. Furthermore, the groups [Adipicola + Bathymodiolus + Benthomodiolus + Gigantidas + Idas + Myrina + Tamu $],[$ Brachidontes + Geukensia + Hormomya], [Fungiacava + Leiosolenus], and $[$ Musculista + Musculus + Mytilus + Septifer $]$ also exhibit monophyly. In the present tree, F. eilatensis is a sister taxon of Leiosolenus simplex.

\section{Shell microstructure}

Shells of all of the observed species consisted of three layers: outer, middle, and inner shell layers. The outer shell layer was composed of either one or two of the following three shell microstructures: fibrous prism

Fig. 1. The strict consensus tree of the mytilid genera composed from the 2 trees constructed using the maximum likelihood and Bayesian methods. The nodes on which the topologies of the 2 trees were not concordant are indicated as polytomies. The mark - on a node indicates bootstrap value $>50 \%$ and Bayesian posterior probability $>0.90$ for the respective monophyletic clade. The branch length was calculated using the maximum likelihood method. 


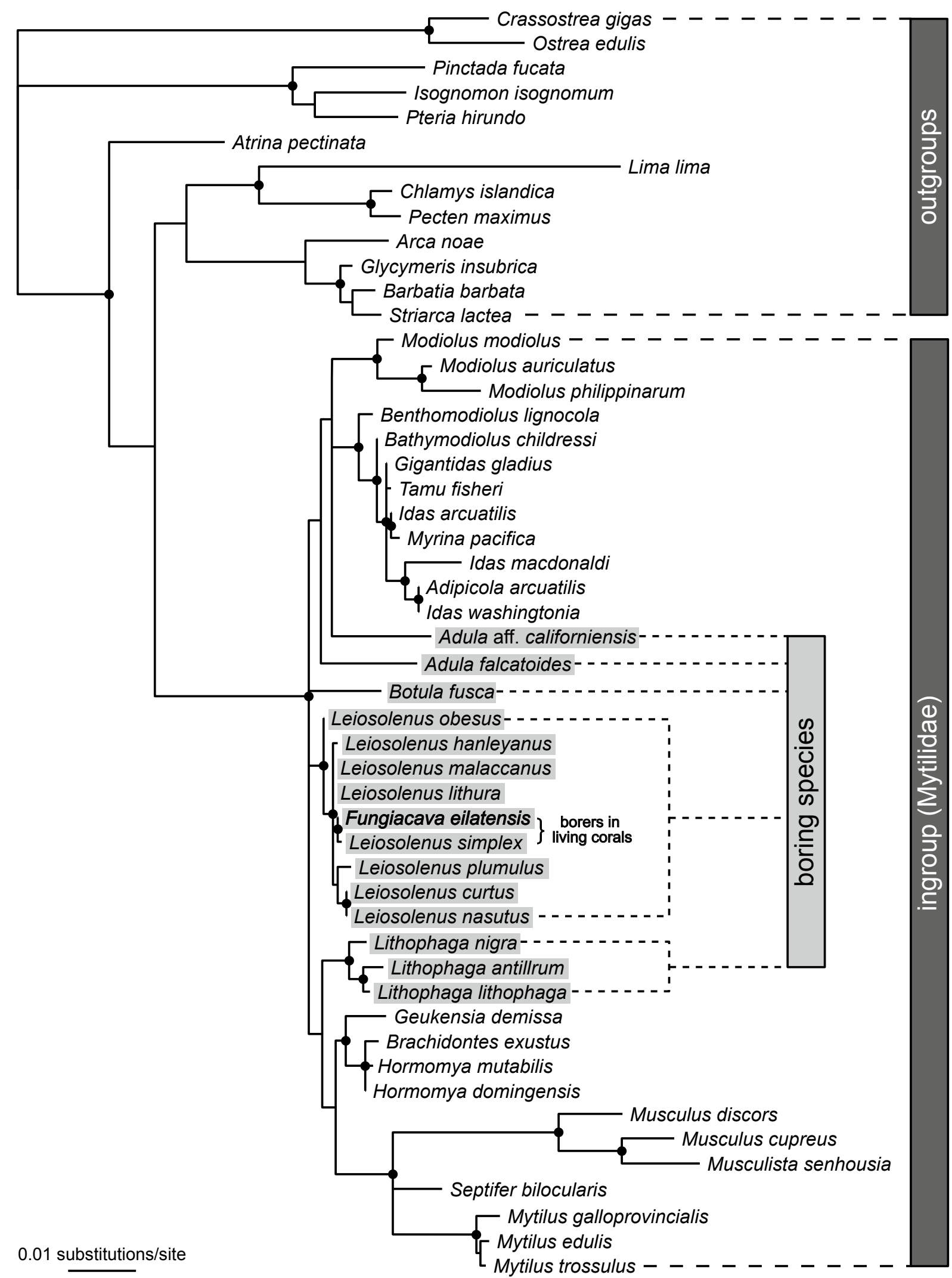



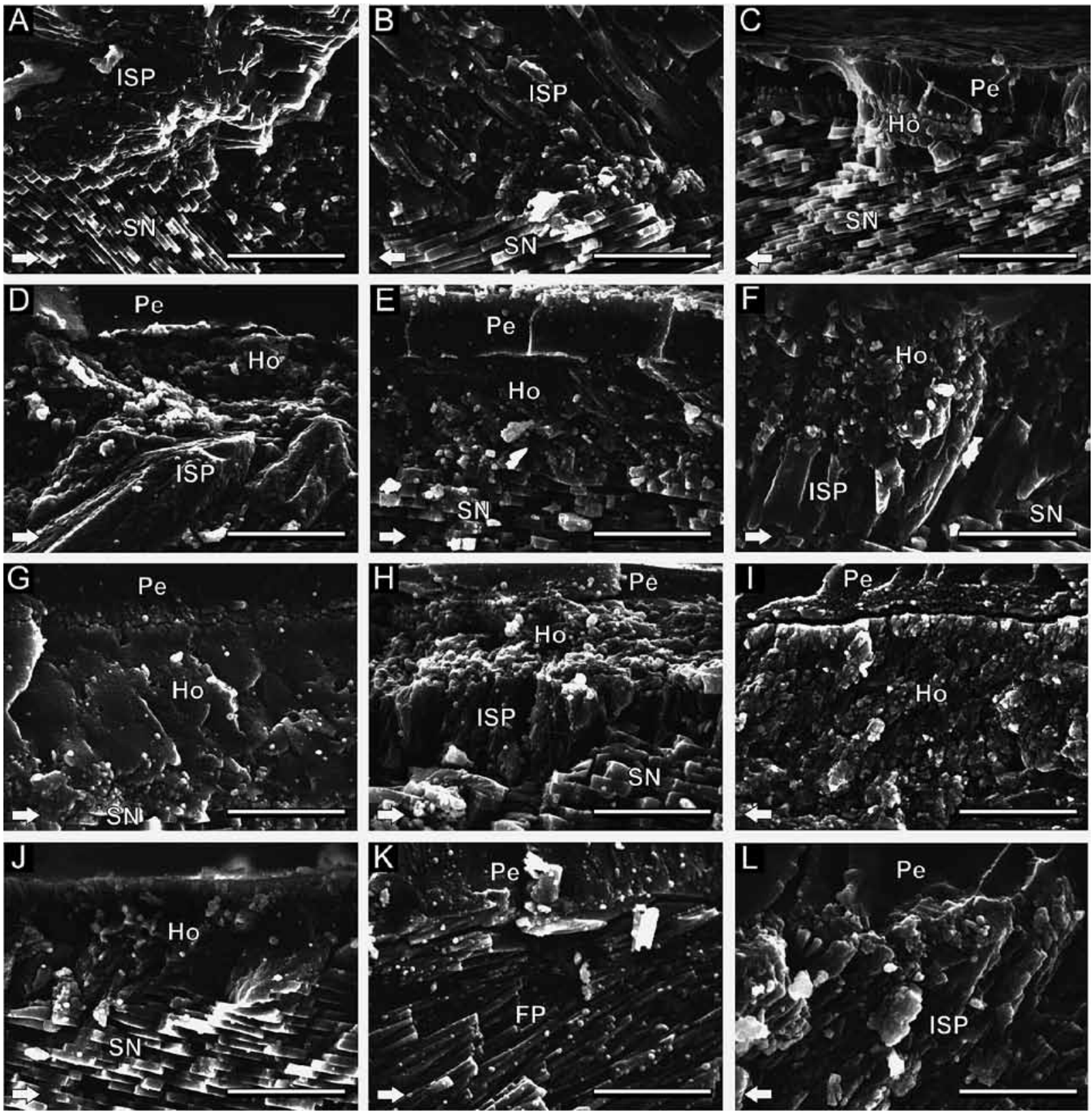

Fig. 2. Shell microstructures observed using SEM. The outer shell layer is partially shown. The arrows indicate the direction of the umbo. The scale bars indicate $10 \mu \mathrm{m}$. FP: fibrous prism structure, Ho: homogeneous structure, ISP: irregular simple prism structure, Pe: periostracum, SN: sheet nacreous structure. A: Adula aff. californiensis, B: Brachidontes setigera (Dunker, 1856), C: Fungiacava eilatensis, D: Hormomya mutabilis, E: Leiosolenus simplex, F: Modiolus auriculatus, G: Modiolus flavidus (Dunker, 1857), H: Modiolus philippinarum, I: Musculus cupreus, J: Musculus senhousia, K: Mytilus galloprovincialis, L: Septifer bilocularis.

(FP) structure, homogeneous (Ho) structure, and irregular simple prism (ISP) structure (Fig. 2, Table 3). The ISP structure of the outer shell layer was consistently observed in Adula, Leiosolenus, Lithophaga, and Modiolus, though it was absent in some species of Leiosolenus and Modiolus. The middle shell layer was composed of the sheet nacreous (SN) structure in all observed species. The inner shell layer of most species was composed of the ISP structure, except in Hormomya mutabilis and Septifer bilocularis, in 
which the inner shell layer was composed of alternating ISP and SN structures. The ISP structure was absent in Mytilus galloprovincialis. The outer shell layer of F. eilatensis was Ho structure, and the shell microstructure of each layer was similar to that of each layer of Leiosolenus malaccanus and L. simplex (see Fig. 4-E in Owada, 2009).

\section{Discussion}

\section{Phylogeny of Fungiacava and Leiosolenus}

Fungiacava was included in the Leiosolenus clade of mussels that live as endosymbionts in living corals, and forms a sister taxon of L. simplex. Musculus and Musculista, which belong to the Crenellinae, did not form a clade with Fungiacava. Furthermore, the shell microstructure of F. eilatensis was more similar to that of L. malaccanus and L. simplex than that of Musculus cupreus and Musculista senhousia. These observations suggest that $F$. eilatensis has descended from a coral-boring Leiosolenus species.

The fossil record suggests that Leiosolenus dates back to the Jurassic and that the symbiosis between Leiosolenus and the corals was established since the Cretaceous (Kleemann, 1983, 1990, 1994, 1996). Fungiid corals appeared since the Paleocene, and the number of species has increased since the Miocene (Wells, 1966; Hoeksema, 1989). Furthermore, the symbiosis between Fungiacava and the fungiid corals was not established before the Pleistocene (Goreau et al., 1976). The time period of the establishment of symbiosis between Leiosolenus and fungiid corals is uncertain. However, one of the Leiosolenus lineages must have diverged into Fungiacava between the Paleocene, the period to which the earliest known presence of Fungiidae has been attributed, and the Pleistocene, the period from which the earliest specimens of Fungiacava has been recorded. Since Fungiacava is found in 14 mushroom coral species (Hoeksema and Kleemann, 2002) distributed over eight genera (Gittenberger et al., 2011), it is likely that the association between Fungiacava and the Fungiidae evolved early in this period, unless Fungiacava has only recently become a generalist with regard to its host preferences.

Juvenile free-living fungiids are attached to a hard substratum and break loose before they reach their adult stage (Hoeksema, 1989; Yamashiro and Yamazato, 1996; Vizel et al., 2009). Their mode of life is quite different from that of the attached fungiid species (see e.g. Hoeksema, 2009) since they can move towards different types of substrata, including sand and silt (Hoeksema and Moka, 1989; Hoeksema and Koh, 2009). Of the 14 recorded mushroom coral hosts of $F$. eilatensis, only two species are unable to detach from the substratum. Because these attached species are closely related to free-living host species (Hoeksema, 1989, 1991a; Gittenberger et al., 2011), the original appearance of Fungiacava in the evolutionary history of the Fungiidae appears to be related to the detached growth form of mushroom corals. Owing to their mobility, mushroom corals may form mixed multi-species assemblages (Hoeksema, 1991b; Hoeksema and Koh, 2009; Hoeksema and Matthews, 2011), and the boring mussels move along with their hosts over the reef bottom. This may facilitate their infestation success, especially if the symbionts are not host-specific. On the other hand, it is remarkable that some mushroom coral species that are known to reach high population densities, such as Zoopilus echinatus Dana, 1846, Halomitra clavator Hoeksema, 1989, Heliofungia actiniformis (Quoy \& Gaimard, 1833) and Heliofungia fralinae (Nemenzo, 1955) are not infested by Fungiacava. $Z$. echinatus and $H$. clavator are thin mushroom corals, which can form large aggregations of loose fragments (Hoeksema and Gittenberger, 2010). They usually do not offer much space to boring organisms and when they break, endosymbionts may become more easily exposed to predators. Furthermore, the mushroom coral species $H$. actiniformis and $H$. fralinae both have fleshy polyps and may also form large aggregations (Hoeksema, 1989). They may reproduce asexually by growing many buds on vacated stalks in $H$. actiniformis (Hoeksema, 1989; Knittweis et al., 2009) or on dying parent corals in H. fralinae (Hoeksema, 2004). Mushroom corals with fleshy polyps may be difficult to infest by coral-boring mussels, and since live-coralboring bivalves benefit from a long life span of their host corals for their own survival, corals that die easily are not a suitable habitat for them. Therefore, the success of the host selection for Fungiacava may be related to the special niche that they have entered with their free-living hosts.

\section{Taxonomical position of Fungiacava}

In the Mytilidae, both Leiosolenus and Lithophaga are characterized by an elongated cylindrical shell form (Newell, 1969). In addition, Leiosolenus is classified by the calcareous incrustations covering the periostracum, while Lithophaga lacks such incrustations (Oliver, 
1992). The shell microstructure characters of the two genera are quite different (Table 3), and the genetic distance is also large (Owada, 2007, 2009). The shell form of Fungiacava looks like that of Solamen (Crenellinae) rather than that of the two aforementioned genera, and the calcareous incrustations are not observed on the periostracum (Goreau et al., 1969). However, the shell microstructure characters of Fungiaca$v a$ are very similar to those of Leiosolenus (Table 3), and Fungiacava was included in the Leiosolenus clade of the present molecular phylogenetic tree (Fig. 1). Therefore, it would be adequate for Fungiacava to be treated as Leiosolenus, but its unique heart-shaped shell form is a reason to keep it a separate genus, as originally proposed by its authors (Goreau et al., 1968, 1969).

\section{Acknowledgements}

We would like to express our deep thanks to K. Kanazawa (Kanagawa University) for the support of this study. We are grateful to T. Haga (JAMSTEC) for donating samples and providing valuable comments. We are indebted to A. Hino (Kanagawa University) for helping with the DNA sequencing experiments and S. Suzuki (Kanagawa University) for helping with the SEM observations. The field research at Ternate was sponsored by the Research Centre for Oceanography, Indonesian Institute of Sciences (PPO-LIPI). The research permit was issued by the Indonesian State Ministry of Research and Technology (RISTEK). We also thank to two anonymous reviewers whose comments and suggestions helped significantly improve the manuscript.

\section{References}

Campbell DC. 2000. Molecular evidence on the evolution of the Bivalvia. Pp 31-46 in: Harper EM, Taylor JD, Crame JA, eds, Evolutionary biology of the Bivalvia. London: Geological Society.

Carter JG, ed., 1990. Skeletal Biomineralization: Patterns, Processes and Evolutionary Trends. New York: Van Nostrand Reinhold.

Distel DL. 2000. Phylogenetic relationships among Mytilidae (Bivalvia): 18s rRNA data suggest convergence in mytilid body plans. Molecular Phylogenetics and Evolution 15: 25-33.

Distel DL, Baco AR, Chuang E, Morrill W, Cavanaugh C, Smith CR. 2000. Do mussels take wooden steps to deep-sea vents? Nature 403: 725-726.

Dunker W. 1856. Mytilacea nova collectionis Cumingianae. Proceedings of the Zoological Society of London 24: 358-366.

Dunker W. 1857. Clausilia lanzai Dunker. Malakozoologische Blätter 4: 232.

Frischer M, Williams J, Kenchington E. 1998. A molecular phylogeny of some major groups of Pectinidae inferred from 18S rRNA gene sequences. Pp. 213-221 in: Johnston PA,
Haggart JW, eds, Bivalves: an eon of evolution - paleobiological studies honoring Norman D. Newell. Calgary: University of Calgary Press.

Giribet G, Wheeler WC. 2002. On bivalve phylogeny: a highlevel analysis of the Bivalvia (Mollusca) based on combined morphology and DNA sequences. Invertebrate Biology 121: 271-324.

Gittenberger A, Reijnen BT, Hoeksema BW. 2011. A molecularly based phylogeny reconstruction of mushroom corals (Scleractinia: Fungiidae) with taxonomic consequences and evolutionary implications for life history traits. Contributions to Zoology 80: 107-132.

Goreau TF, Goreau NI, Goreau TJ, Carter JG. 1976. Fungiacava eilatensis burrows in fossil Fungia (Pleistocene) from the Sinai Pensinsula. Proceedings of the Royal Society of London, Series B, Biological sciences 193: 245-252.

Goreau TF, Goreau NI, Yonge CM, Neumann Y. 1970. On feeding and nutrition in Fungiacava eilatensis (Bivalvia, Mytilidae), a commensal living in fungiid corals. Journal of Zoology 160: 159-172.

Goreau TF, Goreau NI, Neumann Y. 1968. Fungiacava eilatensis n. gen., n. sp. (Bivalvia, Mytitidae), a boring bivalve commensal in reef corals. American Zoologist 8: 799.

Goreau TF, Soot-Ryen T, Yonge CM. 1969. On a new commensal mytilid (Mollusca: Bivalvia) opening into the coelenteron of Fungia scutaria (Coelenterata). Journal of Zoology 158: 171-195.

Groenenberg DSJ, Wesselingh FP, Rajagopal S, Jansen JM, Bos MM, Van der Velde G, Gittenberger E, Hoeksema BW, Raad H, Hummel H. 2011. On the identity of broad-shelled mussels (Mollusca, Bivalvia, Mytilus) from the Dutch delta region. Contributions to Zoology 80: 95-106.

Hoeksema BW. 1989. Taxonomy, phylogeny and biogeography of mushroom corals (Scleractinia: Fungiidae). Zoologische Verhandelingen Leiden 254: 1-295.

Hoeksema BW. 1991a. Evolution of body size in mushroom corals (Scleractinia: Fungiidae) and its ecomorphological consequences. Netherlands Journal of Zoology 41: 122-139.

Hoeksema BW. 1991b. Control of bleaching in mushroom coral populations (Scleractinia: Fungiidae) in the Java Sea: stress tolerance and interference by life history strategy. Marine Ecology Progress Series 74: 225-237.

Hoeksema BW. 1993. Historical biogeography of Fungia (Pleuractis) spp. (Scleractinia: Fungiidae), including a new species from the Seychelles. Zoologische Mededelingen Leiden 67: 639-654.

Hoeksema BW. 2004. Impact of budding on free-living corals at East Kalimantan, Indonesia. Coral Reefs 23: 492.

Hoeksema BW. 2009. Attached mushroom corals (Scleractinia: Fungiidae) in sediment-stressed reef conditions at Singapore, including a new species and a new record. Raffles Bulletin of Zoology, Supplement 22: 81-90.

Hoeksema BW, Achituv Y. 1993. First Indonesian record of Fungiacava eilatensis Goreau et al., 1968 (Bivalvia: Mytilidae), endosymbiont of Fungia spp. (Scleractinia: Fungiidae). Basteria 57: 131-138.

Hoeksema BW, Gittenberger A. 2008. Records of some marine parasitic molluscs from Nha Trang, Vietnam. Basteria 72 : 129-133.

Hoeksema BW, Gittenberger A. 2010. High densities of mushroom coral fragments at West Halmahera, Indonesia. Coral Reefs 29: 691. 
Hoeksema BW, Kleemann K. 2002. New records of Fungiacava eilatensis Goreau et al., 1968 (Bivalvia, Mytilidae) boring into Indonesian mushroom corals (Scleractinia, Fungiidae). Basteria 66: 25-30.

Hoeksema BW, Koh EGL. 2009. Depauperation of the mushroom coral fauna (Fungiidae) of Singapore (1860s-2006) in changing reef conditions. Raffles Bulletin of Zoology, Supplement 22: 91-101.

Hoeksema BW, Matthews JL. 2011. Contrasting bleaching patterns in mushroom coral assemblages at Koh Tao, Gulf of Thailand. Coral Reefs 30: 95.

Hoeksema BW, Moka W. 1989. Species assemblages and ecomorph variation of mushroom corals (Scleractinia: Fungiidae) related to reef habitats in the Flores Sea. Netherlands Journal of Sea Research 23: 149-160.

Jones WJ, Won YJ, Maas PAY, Smith PJ, Lutz RA, Vrijenhoek RC. 2006. Evolution of habitat use by deep-sea mussels. Marine Biology 148: 841-851.

Kenchington E, Landry D, Bird CJ. 1995. Comparison of taxa of the mussel Mytilus (Bivalvia) by analysis of the nuclear small-subunit RNA gene sequence. Canadian Journal of Fisheries and Aquatic Sciences 52: 2613-2620.

Kenchington E, Naidu KS, Roddick DL, Cook DI, Zouros E. 1993. Use of biochemical genetic markers to discriminate between adductor muscle of the sea scallop (Placopecten magellanicus) and the iceland scallop (Chlamys islandica). Canadian Journal of Fisheries and Aquatic Sciences 50: 1222-1228.

Kleemann K. 1980. Boring bivalves and their host corals from the Great Barrier Reef. The Journal of Molluscan Studies 46: $13-54$.

Kleemann K. 1983. Catalogue of recent and fossil Lithophaga (Bivalvia). The Journal of Molluscan Studies, Supplement 12: $1-46$

Kleemann K. 1990. Evolution of chemically-boring Mytilidae (Bivalvia). Pp. 111-124 in: Morton B, ed., The Bivalvia Proceedings of a Memorial Symposium in Honour of Sir Charles Maurice Yonge, Edinburgh, 1986. Hong Kong: Hong Kong University Press.

Kleemann K. 1994. Associations of coral and boring bivalves since the Late Cretaceous. Facies 31: 131-140.

Kleemann K. 1996. Biocorrosion by bivalves. Marine Ecology 17: $145-158$.

Kleemann K, Hoeksema BW. 2002. Lithophaga (Bivalvia: Mytilidae), including a new species, boring in mushroom corals (Scleractinia: Fungiidae) at South Sulawesi, Indonesia. Basteria 66: 11-24.

Knittweis L, Jompa J, Richter C, Kochzius M. 2009. Population dynamics of the mushroom coral Heliofungia actiniformis in the Spermonde Archipelago, South Sulawesi, Indonesia. Coral Reefs 28: 793-804.

Kobayashi I. 1988. Shell structure and phylogeny of bivalves. Pp 97-146 in: Omori M, Suga S, Goto M, eds, Biomineralization and Phylogeny of Marine Organisms. Tokyo: Tokai University Press [in Japanese].

Kobayashi I. 2004. Internal shell structure and evolution of bivalves. Pp. 139-174 in: Ozawa T, Setoguchi T, Hayami I, eds, Sciences of Palaeobios, evolution of Palaeobios, vol. 4. Tokyo: Asakura Publishing [in Japanese].
Mokady O, Loya Y, Lazar B. 1998. Ammonium contribution from boring bivalves to their coral host - a mutualistic symbiosis? Marine Ecology Progress Series 169: 295-301.

Morton B. 1990. Corals and their bivalve borers - the evolution of a symbiosis. Pp. 11-46 in: Morton B, ed., The Bivalvia Proceedings of a Memorial Symposium in Honour of Sir Charles Maurice Yonge, Edinburgh, 1986. Hong Kong: Hong Kong University Press.

Nemenzo F. 1955. Systematic studies on Philippine shallowwater scleractinians I. Suborder Fungiida. Natural and Applied Science Bulletin 15: 3-84, pls. 1-14.

Newell ND. 1969. Subclass Pteriomorphia. Pp. N248-N393 in: Moore RC, ed., Treatise on invertebrate paleontology, Part N, vol 1, Mollusca 6, Bivalvia. Lawrence: Geological Society of America and University of Kansas Press.

Oliver PG. 1992. Bivalved seashells of the Red Sea. Natural Museum of Wales, UK.

Owada M. 2007. Functional morphology and phylogeny of the rock-boring bivalves Leiosolenus and Lithophaga (Bivalvia: Mytilidae): a third functional clade. Marine Biology 150: 853-860.

Owada M. 2009. Organic sheets in the shells of endolithic mytilids (Bivalvia: Mytilidae). Paleontological Research 13: 159-166.

Quelch JJ. 1886. Report on the reef-corals collected by H.M.S. Challenger during the years 1873-76. Report of the Scientific Results of the Voyage of H.M.S. Challenger. Zoology 16 (3).

Quoy JRC, Gaimard JP. 1833. Zoophytes. Pp. 175-254 in: Voyage de découvertes de l'Astrolabe exécuté par ordre du Roi, pendant les années 1826-1827-1828-1829, sous le commandement de M. J. Dumont d'Urville, Zoologie 4. Paris: J. Tastu.

Quoy JRC, Gaimard JP. 1835. Mollusques. Voyage de découvertes de l'Astrolabe exécuté par ordre du Roi, pendant les années 1826-1827-1828-1829, sous le commandement de M. J. Dumont d'Urville, Zoologie 3, Paris: J. Tastu.

Posada D, Crandall KA. 1998. Modeltest: testing the model of DNA substitution. Bioinformatics 14: 817-818.

Posada D, Buckley TR. 2004. Model selection and model averaging in phylogenetics: advantages of the AIC and Bayesian approaches over likelihood ratio tests. Systematic Biology 53: 793-808.

Ronquist F, Huelsenbeck JP. 2003. MrBayes 3: Bayesian phylogenetic inference under mixed models. Bioinformatics 19: 1572-1574.

Taylor JD, Kennedy JM, Hall A. 1969. The shell structure and mineralogy of the Bivalvia. Introduction. Nuculacea-Trigonacea. Bulletin of the British Museum, Natural History, Zoology, Supplement 3: 1-125.

Taylor JD, Kennedy JM, Hall A. 1973. The shell structure and mineralogy of the Bivalvia. Lucinacea-Clavagellacea, conclusions. Bulletin of the British Museum, Natural History, Zoology 22: 253-294.

Thompson JD, Gibson TJ, Plewniak F, Jeanmougin F, Higgins DG. 1997. The Clustal X windows interface: flexible strategies for multiple sequence alignment aided by quality analysis tools. Nucleic Acids Research 24: 4876-4882.

Swofford DL. 1997. PAUP* 4.0 (phylogenetic analysis using parsimony). Sunderland: Sinauer Associates. 
Vizel M, Kramarsky-Winter E, Loya Y. 2009. Mushroom coral regeneration from a detached stalk. Coral Reefs 28: 939.

Vos RA. 2003. Accelerated likelihood surface exploration: The likelihood ratchet. Systematic Biology 52: 368-373.

Wells JW. 1966. Evolutionary development in the scleractinian family Fungiidae. Pp. 223-246 in: Rees WJ, ed., The Cnidaria and their evolution, Symposia of the Zoological Society of London, No. 16. London: Academic Press
Yamashiro H, Yamazato K. 1996. Morphological studies of the soft tissues involved in skeletal dissolution in the coral Fungia fungites. Coral Reefs 15: 177-180.

Received: 21 October 2010

Revised and accepted: 15 January 2011

Published online: 22 June 2011

Editor: M. Schilthuizen 